\title{
PERANAN KEMASAN (PACKAGING) DALAM \\ MENINGKATKAN PEMASARAN PRODUK USAHA MIKRO \\ KECIL MENENGAH (UMKM) DI "MAS PACK” TERMINAL KEMASAN PONTIANAK
}

\author{
Ari Widiati \\ Institut Agama Islam Negeri Pontianak \\ Email : ariwidiati.iain@yahoo.com
}

\begin{abstract}
ABSTRAK
Usaha Mikro Kecil dan Menengah (UMKM) merupakan tulang punggung perekonomian nasional. Sektor ini mampu menggerakkan perekonomian masyarakat dan menyerap tenaga kerja dalam jumlah besar. Sayangnya, kemasan (packaging) produk UMKM belum bisa bersaing dengan produk pabrikan. "Mas Pack" Terminal Kemasan Pontianak adalah solusinya. "Mas Pack" dapat merubah kemasan biasa menjadi kemasan yang standar sehingga bisa meningkatkan pemasaran produk UMKM. Dengan memperbaiki kemasan UMKM terbukti dapat meningkatkan pemasaran, segmen pasarnya semakin bertambah, dan omset pemasaran semakin meningkat sehingga dapat mewujudkan UMKM naik kelas.
\end{abstract}

Kata Kunci : Kemasan, Produk, UMKM, Pemasaran 


\section{PENDAHULUAN}

Usaha Mikro Kecil dan Menengah (UMKM) merupakan tulang punggung perekonomian nasional. Sektor ini mampu menggerakkan perekonomian masyarakat dan menyerap tenaga kerja dalam jumlah besar. Untuk itu Pemerintah melalui Gerakan Kewirausahaan Nasional 2014 semakin meningkatkan pembinaan kepada UMKM terutama membantu mengatasi masalah-masalah yang dihadapi oleh UMKM. Salah satu masalah yang sering dihadapi oleh usaha mikro kecil dan menengah (UMKM) adalah kemasan yang masih sederhana. Perlu diakui bahwa produk-produk yang dihasilkan oleh UMKM sangat enak dan bagus tidak kalah dengan produk yang dihasilkan oleh pabrikan. Namun karena produk UMKM tersebut kemasannya sederhana sehingga penampilannya kurang menarik. Hal inilah yang menyebabkan produk UMKM jangkauan pasarnya terbatas, sulit bersaing dipasaran apalagi pasar modern.

Menurut Kementerian Negara Koperasi Dan Usaha Kecil Dan Menengah (2009) Bahwa Koperasi Usaha Kecil Dan Menengah (KUKM) Pangan adalah salah satu KUKM yang mempunyai potensi dalam pengembangan perekonomian Nasional. Dengan berjalannya waktu KUKM makanan dan Minuman Indonesia akan tergilas oleh makanan dan minuman impor apabila tidak meningkatkan mutu hasil produksi dan kemasannya.

Sesuai Undang-Undang No. 20 Tahun 2008 Tentang Usaha Mikro, Kecil dan Menengah yang dimaksud :

1. Usaha mikro adalah usaha produktif milik orang perorangan dan / atau badan usaha perorangan yang memenuhi kriteria usaha mikro sebagaimana diatur dalam undangund ang ini.

2. Usaha kecil adalah usaha ekonomi produktif yang berdiri sendiri, yang dilakukan oleh orang perorangan atau badan usaha yang bukan merupakan anak perusahaan atau bukan cabang perusahaan yang dimiliki, dikuasai, atau menjadi bagian baik langsung maupun tidak langsung dari usaha menengah atau usaha besar yang memenuhi kriteria usaha kecil sebagaimana dimaksud dalam undang-undang ini.

3. Usaha menengah adalah usaha ekonomi produktif yang berdiri sendiri, yang dilakukan oleh orang perorangan atau badan usaha yang bukan merupakan anak perusahaan atau cabang perusahaan yang dimiliki, dikuasai, atau menjadi bagian baik langsung maupun tidak langsung dengan usaha kecil atau usaha besar dengan 
jumlah kekayaan bersih atau hasil penjualan tahunan sebagaimana diatur dalam und ang-und ang ini.

"Mas Pack" Terminal Kemasan Pontianak adalah solusi agar kemasan UMKM tampil lebih menarik dan tidak kalah dengan produk pabrikan. Karena itu dalam mendesain sebuah kemasan, hendaklah dibuat dengan bentuk, warna, dan tulisan yang menarik dan unik sehingga tampak berbeda dengan yang lainnya. Kemasan yang unik akan mencuri perhatian konsumen untuk memperhatikan produk UMKM dan kemudian akan mempertimbangkannya untuk membelinya. Bisa saja terjadi, seorang konsumen pada awalnya tidak tahu produk anda, tapi karena produk UMKM memiliki kemasan yang menarik maka ia menjadi tertarik dan membelinya.

Pada dasarnya desain kemasan mempengaruhi apa yang ada di dalamnya. Karena itu pengaruh bentuk, warna, bahan, desain kemasan dapat mempengaruhi konsumen. Perilaku konsumen yang semakin kritis terhadap kemasan produk, terlebih untuk kemasan produk makanan harus mendapat perhatian khusus. Menggunakan bahan yang ramah lingkungan, mudah dibawa, serta aman dan tidak menimbulkan kontaminasi pada makanan, serta memberikan informasi produk yang memadai akan menjadi pilihan konsumen.

Selain faktor-faktor tersebut anda juga harus memperhatikan apa yang menjadi tren di masyarakat. Kemasan yang tidak up-to-date akan memberikan kesan produk anda ketinggalan jaman, kecuali jika memang produk anda sudah dikenal luas dan memiliki brand awareness yang kuat.

Kemasan yang bagus tentu akan mempengaruhi harga produk. Untuk itu UMKM harus memiliki strategi pemasaran untuk menyiasatinya. Namun bagi sebagian konsumen yang sangat mengutamakan mutu, harga tidaklah masalah jika memang produk yang ditawarkan benar-benar berkualitas. Maka terkait dengan hal tersebut fokus dari penelitian ini adalah 1) Bagaimana kemasan pada produk UMKM Pontianak? 2) Bagaimana peran kemasan dalam meningkatkan pemasaran produk UMKM di "Mas Pack” Terminal Kemasan Pontianak?

\section{PEMBAHASAN}




\section{Kemasan (packaging) pada produk UMKM Pontianak}

Menurut Kementerian Negara Koperasi Usaha Kecil Dan Menengah (2009) Kemasan atau packaging adalah ilmu, seni dan teknologi yang bertujuan untuk melindungi sebuah produk saat akan dikirim, disimpan atau dijajakan.

Pengemasan (packaging) secara sederhana dapat juga diartikansebagai suatu cara untuk menyampaikan barang kepada konsumen dalam keadaan terbaik dan menguntungkan. Dalam era globalisasi saat ini, kemasan mempunyai peran yang sangat penting karena akan selalu terkait dengan komoditi yang dikemas dan sekaligus merupakan nilai jual dan citra produk. Packaging is a silent salesman. Produk merupakan gabungan antara isi dan kemasan. Banyak pihak yang mengatakan bahwa kemasan hanya merupakan sampah dan menambah beban biaya penjualan. Namun tidak demikian adanya, kemasan yang standar dapat mengangkat citra suatu produk, memberikan nilai tambah dalam penjualan dan dapat melindungi produk dengan baik. Kemasan harus dapat memenuhi harapan konsumen. Kemasan bisa memberikan perlindungan produk dengan baik dari cuaca, cahaya/sinar, perubahan suhu, jatuh, tumpukan, kotoran, serangga, bakteri dan lain-lain. Struktur kemasan mudah dibuka, mudah ditutup dan mudah dibawa (ergonomi). Bentuk dan ukuran menarik sesuai dengan kebutuhan menciptakan daya tarik visual bagi konsumen. Bentuk fisik kemasan ditentukan oleh sifat produk itu sendiri, sistem penjualan, mekanis, display, distribusi dan segmen pasar. Labeling harus jelas dan lengkap dan disain kemasan dirancang unik dan khas sehingga tampak berbeda dengan produk lain.

Peran kemasan pada produk adalah 1) Sebagai wadah yang memungkinkan diangkutnya suatu produk atau barang dari satu tempat ketempat yang lain atau dari produsen ke konsumen. 2) Melindungi produk yang dikemas dari pengaruh cuaca, benturan, tumpukan dan lain-lain. 3) Memberikan informasi, brand image dan sebagai media promosi dengan pertimbangan mudah dilihat, dipahami serta diingat. Sehingga kebutuhan kemasan dalam memberi informasi menjadi bagian yang paling penting. Pemberian label dan merek pada makanan dan produk lain sangat penting sebagai pembeda terhadap pesaing. Agar desain kemasan tampil menarik dapat dikonsultasikan pada desainer kemasan.

Desain kemasan harus menjadi media komunikasi antara produsen dengan calon konsumen, sehingga dalam desain kemasan perlu dicantumkan 1) Nama produk 2) 
Komposisi 3) isi/netto. Kemasan standar yang menarik dapat dikatakan bisa menjual dirinya sendiri. Sehingga dapat meningkatkan penjualan karena bisa memasuki ke segmen-segmen pasar yang lain.

Direktorat Jenderal Pengelolahan dan Pemasaran Hasil Pertanian Kementerian Pertanian Republik Indonesia (2012) menginformasikan fungsi kemasan adalah

1. Melindungi dan mengawetkan produk, seperti melindungi dari sinar ultraviolet, panas, kelembaban udara, benturan seta kontaminasi kotoran dan mikroba yang dapat merusak dan menurunkan mutu produk

2. Sebagai identitas produk, dalam hal ini kemasan dapat digunakan sebagai alat komunikasi dan informasi kepada konsumen melalui merek yang tertera pada kemasan

3. Meningkatkan efisiensi, seperti memudahkan proses penghitungan, pengiriman dan penyimpanan produk

Ada beberapa jenis kemasan yaitu 1) Kemasan Primer (consumer pack) adalah kemasan yang langsung berhubungan/bersentuhan dengan produk, biasanya ukuran relatif kecil dan disebut juga kemasan eceren. Sebagai contoh kemasan makanan ringan/snack, kemasan sachet untuk sampo, deterjen, kecap, saos tomat, mie instant, gelas plastik (cup) dan lain-lain. 2) Kemasan Sekunder (transport pack) adalah kemasan kedua yang isinya sejumlah kemasan sekunder. Jenis kemasan ini tidak langsung berhubungan/kontak dengan produk yang dikemas. Sebagai contoh kemasan karton/kardus mie instant, kemasan karton/kardus air minum dalam kemasan dan lainlain. 3) Kemasan Tersier adalah kemasan ketiga yang isinya sejumlah kemasan sekunder. Kemasan ini fungsinya untuk pengiriman lokal, antar pulau atau antar negara. Memiliki syarat tahan benturan, tahan cuaca dan berkapasitas besar. Sebagai contoh kotak karton bergelombang dan kontainer.

Beberapa bahan kemasan yang biasa digunakan yaitu bahan kemasan kaku/rigid yakni kemasan kayu, logam, metal, besi, kaca dan botol. Sedangkan bahan kemasan lentur/fleksibel biasanya terbuat plastik, kertas, multilayer, nilon/vacum, aluminium foil dan metalized. Penggunaan bahan-bahan kemasan ini disesuaikan dengan karakteristik produk. Untuk produk makanan ringan/snack yang sifatnya seperti keripik pisang, keripik singkong, amplang, keripik buah dan lain biasanya menggunakan bahan aluminium foil atau metalized. Secara struktur kemasan berbahan aluminium foil 
memiliki tiga lapisan yaitu Lapisan cetak (OPP) sebagai pelindung lembab, Lapisan pelindung (Alu Foil) sebagai pelindung udara, cahaya, oksigen/gas dan Lapisan berikutnya adalah Lapisan dalam (PE) sebagai pembungkus dan lapisan seal. Struktur molekul lapisan alu foil secara kimia, fisika, menghalangi transmisi sinar, permeasi O2, gas dan uap air melalui dinding kemasan. Untuk produk semi basah seperti sosis, nuget, bakso, bandeng presto dan lain dapat menggunakan kemasan berbahan nylon/vacum. Kemasan berbahan nylon/vacum memiliki dua lapisan yaitu lapisan pelindung udara atau sinar dan lapisan dalam (PE) sebagai pembungkus dan seal.

Secara umum kemasan sebaiknya bersifat informatif, identifikasi dengan jelas, menyampaikan manfaat dan penggunaannya, mempunyai label yang jelas sesuai dengan peraturan label dan periklanan, efektik, menarik dan memberikan kemudahan.

Rancangan kemasan ditentukan oleh karakteristik produk, proses produksi, jalur distribusi, segmen pasar, produk pesaing, sasaran pasar dan promosi. Kemasan juga sebagai media penandaan barang, warna kemasan mencerminkan isi, ramah lingkungan dan dapat didaur ulang. Agar tampil menarik kemasan perlu didesain sehingga sesuai dengan produk yang dikemas, sesuai dengan tingkat pemasaran yang dituju, up to date, menarik dan dapat diterima, display mudah, komunikatif dan berbeda dari produk pesaing. Desain kemasan meliputi desain bentuk dan desain grafis. Pada kemasan juga perlu ada pelabelan sebagai identifikasi, membantu penjulan produk dan pemenuhan peraturan perundang-undangan. Pemberian merek juga penting sebagai identitas, pembeda terhadap produk pesaing dan jaminan kualitas.

Menurut Kementerian Negara Koperasi Dan UKM RI (2009) ada beberapa hal yang mesti tercantum dalam sebuah kemasan yaitu Nama Produk, Brand atau merek, Logo, Keterangan Tentang Bahan Tambahan Pangan, Keterangan Tentang Bahan Yang Digunakan (Komposisi), Keterangan Tentang Berat Bersih atau Isi Bersih, Keterangan Tentang Tanggal Kadaluarsa, Keterangan Tentang Nama Dan Alamat, Keterangan Tentang Kandungan Gizi, Keterangan Tentang Kode Produksi Pangan, Nomor Pend aftaran Pangan, Klaim Halal, Barcode

Menurut Rhina uchyani dan Heru irianto (2015) kemasan merupakan "pemicu" karena fungsinya langsung berhadapan dengan konsumen dengan demikian, kemasan harus dapat memberikan impresi spontan yang mempengaruh tindakan positif konsumen di tempat penjualan. Dengan situasi persaingan yang semakin tajam, estetika merupakan 
suatu nilai tambah yang dapat berfungsi sebagai "perangkap emosional" yang sangat ampuh untuk menjaring konsumen.

Dengan mengetahui dasar-dasar pengetahuan tentang kemasan standar ini diharapkan Usaha Mikro Kecil Dan Menengah (UMKM) dapat merancang dan membuat kemasan yang standar sehingga penampilan produk mereka dapt semakin menarik disamping itu juga produk UMKM dapat lebih higienis dan sehat. UMKM juga dapat mendatangi desainer kemasan berkonsultasi jika hal tersebut diperlukan. Sehingga diharapkan dengan kemasan standar pemasaran produk UMKM semakin luas dan keuntungan juga semakin meningkat.

Ada beberapa hal yang dapat dilakukan untuk menciptakan kemasan produk terbaik yang dapat memikat hati konsumen yaitu 1) Unik dan kreatif, terlihat beda dengan kemasan produk yang lain walaupun produk sama. 2) Sesuaikan desain kemasan dengan produk, contohnya produk keripik pisang maka desain kemasan dan tampilannnya berupa gambar buah pisang atau animasi buah dan kreativitas dalam desainya. 3) Buat kemasan berbagai ukuran dan bentuk, tujuannnya adalah agar konsumen mudah untuk membeli produk sesuai kebutuhan. 4) Buat kemasan yang dapat didaur ulang, tujuannnya agar biaya tidak mahal, ramah lingkungan dan ikut berperan menjaga kelestarian lingkungan.

\section{Peran kemasan dalam meningkatkan pemasaran produk UMKM di "Mas Pack" Terminal Kemasan Pontianak}

Pengertian pemasaran menurut American Marketing Association (AMA) seperti yang dikutip oleh Rhenald Kasali dalam buku Ita Nurcholifah (2012) adalah suatu proses perencanaan dan eksekusi, mulai tahap konsepsi, penetapan harga, promosi, hingga distribusi barang-barang, ide-ide dan jasa, untuk melakukan pertukaran yang memuaskan individu dan lembaga-lembaganya.

Menurut Boyd, Walker dan Larreche (2000) Pemasaran adalah suatu proses sosial yang melibatkan kegiatan-kegiatan penting yang memungkinkan individu dan perusahaan mendapatkan apa yang mereka butuhkan dan inginkan melalui pertukaran dengan pihak lain dan untuk mengembangkan hubungan pertukaran. 
Pemasaran menurut Thamrin Abdullah Dan Francis Tantri (2016) adalah suatu sistem total dari kegiatan bisnis yang dirancang untuk merencanakan, menentukan harga, mempromosikan dan mendistribusikan barang-barang yang dapat memuaskan keinginan dan jasa baik kepada para konsumen saat ini maupun konsumen potensial.

Pemasaran yang sudah dilakukan di "Mas Pack" Terminal Kemasan Pontianak

1. Melalui website: senyumwirausaha.wordpress.com

Di dalam website tersebut termuat profil kemasan mulai dari bentuk, ukuran dan bahan serta harganya. Konsumen bisa mengetahui tentang berbagai macam kemasan yang ada seperti kemasan kotak, plastik cetak rotografur, cetak sablon dan lainnya. Disamping itu di dalam website juga ada sebagian yang mencantumkan harga kemasan, tetapi sewaktu-waktu bisa berubah.

2. Melalui media sosial seperti face book, what up, instagram, line

Adapun face book yang digunakan untuk melakukan promosi pemasaran adalah ari widiati, senyum wirausaha dan danan muhuda adji saroyo. Konsumen bisa dengan mudah mencari contoh-contoh kemasan, mesin melalui media sosial tersebut.

3. Melalui market place seperti OLX

Pernah dilakukan melalui OLX tetapi sekarang sudah tidak lagi karena tidak di up date.

4. Melalui pelatihan kemasan pada UMKM

Memberikan pelatihan pengemasan standar produk pada UMKM binaan pemda, BUMN, swasta dan komunitas UMKM. Seperti yang biasa dilakukan oleh "Mas Pack” Terminal Kemasan Pontianak adalah di undang menjadi narasumber pada instansi terkait dengan tema packaging dan kewirausahaan

5. Melalui pemasaran langsung ke tempat produksi UMKM

Menawarkan kemasan pada UMKM tersebut disesuaikan kebutuhan dan berkunjung ke tempat UMKM. Hal ini bisa meningkatkan penjualan dan memudahkan konsumen dalam memilih kemasan produknya.

Adanya kemasan yang standar pada UMKM dapat meningkatkan pemasaran dan penjualan pada konsumen. Hal ini sudah dilakukan oleh konsumen "Mas Pack" yang sudah memperbaiki kemasannya. Adapun peran kemasan dalam meningkatkan pemasaran produk UMKM di “Mas Pack” Terminal Kemasan Pontianak adalah: 
a. Mengangkat citra dan nilai tambah dari produk tersebut

Sebuah produk akan mempunyai nilai jual yang lebih apabila kemasannya lebih menarik. Misalnya produk amplang (makanan khas kalbar), amplang dikemas dengan menggunakan kemasan biasa tentunya harga standar tetapi apabila amplang tersebut di beri kemasan aluminium foil kemudian dibungkus menggunakan kotak tentunya mempunyai nilai jual yang tinggi dan segmen pasarnya pun berbeda dengan menggunakan kemasan plastik biasa (polypropilen).

b. Memperpanjang masa simpan produk

Memperpanjang masa simpan misalnya produk kripik menggunakan kemasan biasa (polypropilen) masa simpannya hanya satu bulan tetapi dengan menggunakan kemasan standar (aluminium foil) masa simpannya bisa sampai lebih dari 6 bulan.

c. Dapat mewujudkan UMKM naik kelas

Maksudnya dari yang usahanya masih mikro bisa menjadi usaha kecil. Kemudian dari usaha kecil bisa menjadi usaha menengah. Dari usaha menengah bisa menjadi usaha besar. Tentunya dengan memperluas pemasaran, segmen pasarnya semakin bertambah sehingga omset penjualan semakin meningkat

\section{KESIMPULAN}

Keberadaan kemasan sangat diperlukan oleh Usaha Mikro Kecil dan Menengah (UMKM) yang notabeneya masih menggunakan kemasan yang belum standar. Pengemasan (packaging) diartikan sebagai suatu cara untuk menyampaikan barang kepada konsumen dalam keadaan terbaik dan menguntungkan. Peranan kemasan dalam meningkatkan pemasaran produk di "Mas Pack" Terminal Kemasan Pontianak adalah dapat mengangkat citra dan nilai tambah pada produk tersebut, memperpanjang masa simpan produk dan dapat mewujudkan UMKM naik kelas untuk meningkatkan hasil penjualan.

\section{DAFTAR PUSTAKA}

Kementerian Negara Koperasi Dan Usaha Kecil Dan Menengah.,2009. Pedoman Standar Kelayakan Kemasan Produk KUKM, Jakarta

Boyd, Walker, Larece, 2000. Manajemen Pemasaran Suatu Pendekatan Strategis

Dengan Orientasi Global, Jakarta:Penerbit Erlangga. 
Abdullah, Thamrin Dan Tantri, Francis, 2016. Manajemen Pemasaran, Jakarta: PT. Raja Grafindo Persada.

Nana Herdiana Abdurrahman, Achmad Sanusi, 2015. Manajemen Strategi Pemasaran. Bandung:Pustaka Setia.

Nurcholifah, Ita, 2012. Manajemen Pemasaran. Pontianak:STAIN Pontianak Press.

Kotler, Philip dan Gary Amstrong, 2001. Prinsip Prinsip Pemasaran, Edisi Delapan, Jilid I dan II, Jakarta:Erlangga.

Kotler, Philip, 2012, Manajemen Pemasaran ; Edisi Milenium, Diterjemahkan oleh Hendra Teguh dan Ronny A. Rusli, Edisi Kesembilan, Jilid I an II, Prentice Hall, New Jersey.

Foster, Denis L, 2000, Sales And Marketing For The Travel Profesional, Penerjemah: Tri Budi Satrio.Jakarta: PT. Raja Grafindo Persada.

B Lena Nuryanti, Anisa Yunia Rahman, 2008, pengaruh variasi Dan Kemasan Produk Terhadap Keputusan Pembelian The Kotak Ultra Jaya. Jurnal Strategic, Vol.7, no.14 sept 2008

Rhina Uchyani, Heru Irianto, 2015, Pengemasan Produk Dalam Meningkatkan Produk

Berbahan Baku Kacang Yang Marketable. Laporan Prosiding Seminar Nasional $4^{\text {th }}$ SME's Summit Dan Awards 2015

Undang - Undang RI No. 20 Tahun 2008 Tentang Usaha Mikro, Kecil Dan Menengah

Moleong, Lexy J.2004. Metodologi Penelitian kualitatif Edisi Revisi. Bandung: PT

Remaja Roosdakarya

Nawawi, Hadari. 1997. Metode Penelitian Bidang Sosial. Yogyakarta: Gajah Mada

Syukrianti Mukhtar, Muchammad Nurif, 2015, Peranan Packaging dalam Meningkatkan

Hasil Produksi terhadap Konsumen. Jurnal Sosial Humaniora, Vol. 8 No.2, Nopember 2015

Masayu Endang Apriyanti, 2018, Pentingnya Kemasan Terhadap Penjualan Produk Perusahaan. Jurnal Sosio e-kons, Vol.10 No. 1, April 2018 